\title{
Designer Babies. Selected Law and Ethical Issues
}

\author{
Aleksandra Nowak-Gruca* \\ Cracow University of Economics, Poland
}

Submission: February 09, 2019; Published: February 27, 2019

*Corresponding author: Aleksandra Nowak-Gruca, Cracow University of Economics, Poland

\section{Opinion}

Who doesn't want a tall, beautiful child with high IQ and empathy? As scientific sources indicate, the first designer babies were created in 1989 and born in $1990^{1}$. On November 25, 2018, geneticist He Jiankui of China's Southern University of Science and Technology announced that his lab had successfully used the Crispr-Cas9 gene-editing ${ }^{2}$ system to make the world's first genetically edited human babies. Following this, the question arises whether has he modified the very blueprint of life. In most countries, it is already legal to shape the genomes of our children in various ways, from the abortion of fetuses with Down's syndrome to the screening of embryos during IVF. For many years, it has been possible to do simpler genetic tests on embryos as part of IVF. DNA testing were not useful for diagnosis traits affected by multiple genes, such as diabetes, cancer risk. But new "polygenic" techniques for analysing many genetic regions at once have begun to make this possible. Genomic Prediction is the first company offering fertility clinics a test for screening IVF embryos for disease risk and low intelligence. For ethical reasons, Genomic Prediction won't help parents select high-IQ embryos in this way. But as the researchers say, the idea of using such tests to select embryos predicted to have high intelligence is technologically feasible ${ }^{3}$. Overall, the procedure of pre-implantation genetic diagnosis (PGD, also known as embryo screening) to select for a positive trait is referred to the creation of a "designer baby". The other use for designer babies concerns possible uses of human germline engineering techniques (such as CRISPR) to create desired genetic traits of a child, such as disease resistance, athletic ability, and intelligence. The thought of shaping future generations to fit some pre-imagined ideal of strength and beauty is one that should make us uncomfortable but from a policy perspective, how would we draw the distinction between a medical and enhancement purpose for germline modification? There are many reasons why people want to have genetically related children, and people's interest in doing so is protected by a widely recognised human right. Enhancement of human nature is often juxtaposed against such concepts as: treatment or therapy applicable once a specific disease has been diagnosed. While attempting to define them, it is worth referring to the concepts developed by the World Health Organization (WHO). In the light of the latter, health is a condition characterized by the achievement of physical, mental and social well-being. Disease, for its part, means every disorder (destruction or deviation) of the appropriate structure or function of any part, organ or system of the organism, manifest in a characteristic set of symptoms, whose aetiology, pathology and prognosis may be either known or unknown. Health is accentuated and attention is paid to it in the form of appropriate diagnostics, research and the use of the achievements of medical sciences. Positive perception of the individual's health also includes reproductive health, with particular emphasis on the aspect of responsibility for them.

${ }^{1}$ See A.H. Handyside, E.H. Kontogianni, K. Hardy, R.M/ Winston (1990). Pregnancies from biopsied human preimplantation embryos sexed by Y-specific DNA amplification. Nature. 344 (6268): 768-70. doi:10.1038/344768a0. PMID 2330030.

${ }^{2}$ Genome editing (also called gene editing) is a group of technologies that give scientists the ability to change an organism's DNA. These technologies allow genetic material to be added, removed, or altered at particular locations in the genome. Several approaches to genome editing have been developed. A recent one is known as CRISPR-Cas9, which is short for clustered regularly interspaced short palindromic repeats and CRISPR-associated protein 9. The emergence of the CRISPR-Cas9 system in 2012 enabled precisely targeted alterations to DNA sequences in living cells. The CRISPR-Cas 9 system has generated a lot of excitement in the scientific community because it is faster, cheaper, more accurate, and more efficient than other existing genome editing methods. Genome editing is of great interest in the prevention and treatment of human diseases. Currently, most research on genome editing is done to understand diseases using cells and animal models. Scientists are still working to determine whether this approach is safe and effective for use in people. It is being explored in research on a wide variety of diseases, including single-gene disorders such as cystic fibrosis, hemophilia, and sickle cell disease. It also holds promise for the treatment and prevention of more complex diseases, such as cancer, heart disease, mental illness, and human immunodeficiency virus (HIV) infection. https://ghr.nlm.nih.gov/primer/genomicresearch/genomeediting, access 2019.02.08.

${ }^{3}$ See C. Wilson (2018). Exclusive: A new test can predict IVF embryos' risk of having a low IQ. New Scientist. https://www.newscientist.com/article/ mg24032041-900-exclusive-a-new-test-can-predict-ivf-embryos-risk-of-having-a-low-iq/ access 2019.02.08. 
In Europe the basic legal act protecting the human genome is the Oviedo Convention ${ }^{4}$ The Chapter IV devoted to the protection of the human genome regulates the protection issues, stressing that all interventions aimed at making changes in the human genome can only be carried out for preventive, diagnostic or therapeutic purposes. According to Article 12 tests which are predictive of genetic diseases or which serve either to identify the subject as a carrier of a gene responsible for a disease or to detect a genetic predisposition or susceptibility to a disease may be performed only for health purposes or for scientific research linked to health purposes, and subject to appropriate genetic counseling. Article 14 of Oviedo Convention prohibits the planning and selection of a child's sex (gender selection), except when gender selection is justified due to the risk of a sex-dependent hereditary disease. Unlike in many European countries, preimplantation genetic diagnosis (PGD) is not regulated in the United States. As a result, PGD may be used for any condition for which genetic testing is available, at the discretion of fertility specialists and their patients. Meanwhile in Great Britain, The Nuffield Council on Bioethics has recently announced that the potential use of heritable genome editing interventions to influence the characteristics of future generations could be ethically acceptable in some circumstances, among others: it is intended to secure, and is consistent with, the welfare of a person who may be born as a consequence of interventions using genome edited cells; and it is consistent with social justice and solidarity, i.e. it should not be expected to increase disadvantage, discrimination, or division in society ${ }^{5}$. For the first time in history, humanness extends his dominion not to the outside world, but to himself-his body and mind. For centuries, homo sapiens used tools-for regulating rivers, domestication and crossing animals, and building more and more refined shelters. However, he had no influence on the structure of his body, cognitive processes, aging and mortality. Currently, human corporeality and cognitive abilities are constantly expanded (human enhancement) thanks to convergent NBIC technologies ${ }^{6}$, Artificial Intelligence, Augmented and Virtual Reality.

Millions of people use devices that aim to improve life: from eyeglasses to eyes, stimulation devices, bionic ears, heart valves and artificial limbs. Our world is a constantly changing complex system, and people are part of this ever-changing system. In this context, the evolution of homo sapiens is a continuous process that shapes us now and will shape in the future, in the body and in the mind. Among the future directions for possible changes, a wide range of shaping future generations is indicated. If not regulated well-enough legally, gene editing could soon results unpredictable consequences. As genetic technologies are very costly, only the affluent social groups have access to them. Moreover, certain religious groups or ethnicities might also decide against the use of such medical intervention. Among the most ethical consequences of human enhancement currently controversial, there are issues of guaranteeing equal access to the use of new technologies and the problem of limits of interference in the human body. The question is whether the redefinition of man will not be necessary for the progress of medicine and technology ${ }^{7}$. Undoubtedly unprecedented, rapid civilization progress will soon drastically affect human nature and change the prevailing balance of power in political and social relations.

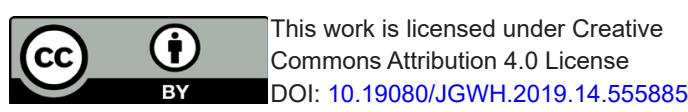

\section{Your next submission with Juniper Publishers will reach you the below assets}

- Quality Editorial service

- Swift Peer Review

- Reprints availability

- E-prints Service

- Manuscript Podcast for convenient understanding

- Global attainment for your research

- Manuscript accessibility in different formats

( Pdf, E-pub, Full Text, Audio)

- Unceasing customer service

Track the below URL for one-step submission

https://juniperpublishers.com/online-submission.php ${ }^{4}$ Convention of the Council of Europe on the Protection of Human Rights and Human Dignity in the Field of Application of Biology and Medicine of April
4, 1997, also called the European Bioethical Convention, supplemented by four additional protocols.

${ }^{5}$ See Nuffield Council on Bioethics (2018) Genome Editing and Human Reproduction: social and ethical issues (London: Nuffield Council on Bioethics).

${ }^{6}$ Nanotechnology, Biotechnology, Information Technology, Cognitive science.

${ }^{7}$ F. Fukuyama (2002) Our Posthuman Future (New York: Farrar, Straus and Giroux), chapter 9 